\title{
A NEW SPECIES OF MICROSORUM (POLYPODIACEAE) FROM THAILAND
}

\author{
THAWEESAKDI BOONKERD \\ Department of Botany, Faculty of Science, Chulalongkorn University, \\ Bangkok 10330, Thailand
}

SUMMARY

A new species, Microsorum siamensis, is described and illustrated.

Key words: Polypodiaceae, Microsorum, new species.

Microsorum siamensis T. Boonkerd, spec. nov. - Fig. 1

Rhizoma 3.2-4.2 mm diametro filis sclerenchymatis 60-240 dispersis squamis peltatis ovatis vel triangularibus $3-3.5 \mathrm{~mm}$ longis, $1-1.3 \mathrm{~mm}$ latis. Frondes subcoreaceae in statu vivo caeruleae iridescentes, in statu sicco brunneae. Lamina simplex $13-23.5 \mathrm{~cm}$ longa, $2.2-4.5 \mathrm{~cm}$ lata, indice $4.5-5.9$, apice longe acuminato, base attenuata, hydathodis manifeste irregulariter dispersis super lamina, soris separatis irregulariter dispersis super venis singularibus vel connectivis in parte apicali laminae, sporas vivide auratus. - Typus: P.V. Fern 1 (holo L; iso BCU), Thailand, Yala.

Rhizome 3.2-4.2 mm in diam., not white waxy, approximately cylindrical with scattered strands of sclerenchyma, vascular bundles in cylinder 9 or 10 , sclerenchyma strands $60-240$, roots densely set, bearing two rows of close to imbricate fronds. Scales densely set, slightly spreading, widest near the base, ovate or triangular, $3-3.5$ by $1-1.3 \mathrm{~mm}$, peltate, margin denticulate, apex acuminate to slightly caudate, clathrate throughout, dark black on central region. Phyllopodia more or less distinct, 3.1-4.1 mm apart. Fronds monomorphous (well proportioned to the rhizome diameter), subcoriaceous, iridescent blue-green in colour when living, Havana brown to raw umber in dry specimens. Lamina simple, hydathodes scattered on upper surface, elliptic to narrowly elliptic, $13-23.5$ by $2.2-4.5 \mathrm{~cm}$, index $4.5-5.9$, base attenuate, the stipe more or less winged, margin entire undulate, apex acute to long acuminate, costa raised on lower surface, slightly raised on upper surface. Venation: connecting veins forming a row of about equally sized areoles between two adjacent veins and no prominent veinlet situated parallel to the veins; the venation is hidden in living specimen, free veinlets simple or 1 or 2 times forked. Sori separate, mostly irregularly scattered on a simple free vein or on 2 or 3 connective veins, usually occupying the upper half portion of the lamina, more or less round, superficial, 4-14 per $\mathrm{cm}^{2}, 0.7-1.6 \mathrm{~mm}$ in diam.; paraphysis absent; sporangium hyaline when young, turning yellowish brown when mature, sporangium annulus 17-21-celled, indurated cells 11-14; spores concavo-convex, brightly golden yellow, $35-38$ by $50-55 \mu \mathrm{m}$. 


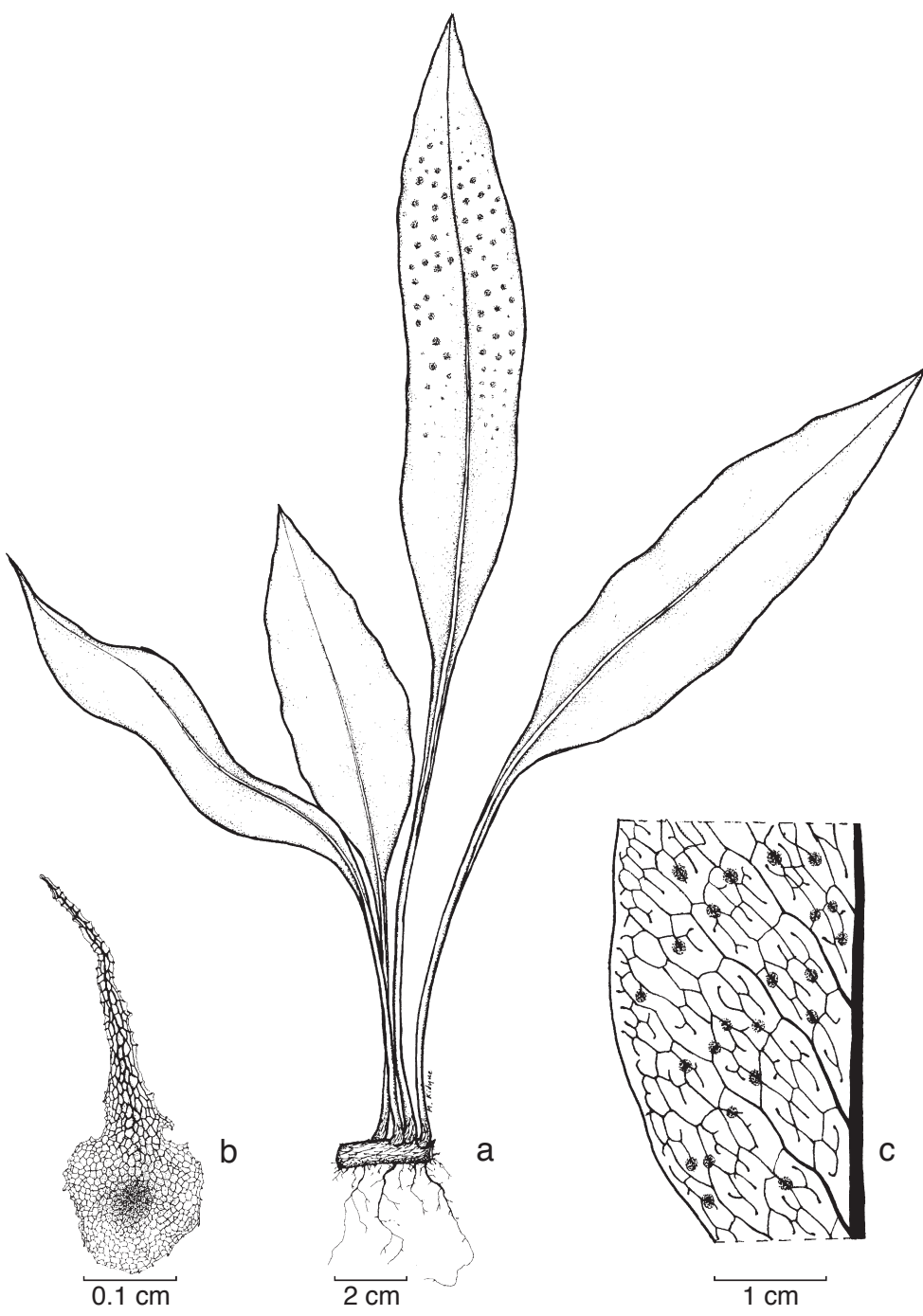

Fig. 1. Microsorum siamensis T. Boonkerd. a. Habit; b. rhizome scale; c. detail of venation (all: P.V. Fern 1). Drawn by Manit Kidyue.

Distribution - Thailand (Yala).

Habitat \& Ecology - In rock crevices on moist rock of limestone hills in semishade, about $100 \mathrm{~m}$ altitude.

Notes - This iridescent blue-green Microsorum species was collected by Mr. Poonsak Vatcharakorn from Peninsular Thailand. It is an easily cultivated species, but still uncommon among enthusiastic fern hobbyist. This species is a lithophyte, occurs in a small population on limestone hills in semi-shade and usually on moist and humus-rich rocks or cliffs. 
So far, it has a natural affinity with Microsorum thailandicum T. Boonkerd \& Noot., but these two species have never been found together in the wild. The new species is easily noticed by numerous prominent hydathodes on the upper surface of the frond. They also differ in shape, breadth, and venation of the lamina. Moreover, mature sporangium size and colour, number of annulus cells and colour of spores are inconsistent.

The specific epithet 'siamensis' refers to Siam, the old name of Thailand where this species was collected.

\section{ACKNOWLEDGEMENTS}

I am grateful to Dr. Hans Nooteboom for his invaluable suggestions and discussions. I thank Mr. Poonsak Vatcharakorn for providing living specimens of this species. Sincere thanks also to members of the 'Plants of Thailand Research Unit', especially Ms. Rossarin Pollawatn and Mrs. Parinyanoot Darumas for their assistance during specimen collection, Mr. Manit Kidyue for his expertise in drawing Fig. 1 and Mr. Sahut Chantanaorrapint for his help with the measurements. Thanks also to Ms. Suchada Wongpakam who has called my attention to this particular fern species. This work was supported by the TRF/BIOTEC Special Program for Biodiversity Research and Training grant (BRT) and the Chulalongkorn University through 'Plants of Thailand Research Unit'. 